USGS-OFR--95-287

DIGITAL ELEVATION MODEL (DEM) FILE OF

TOPOGRAPHIC ELEVATIONS FOR THE DEATH

VALLEY REGION OF SOUTHERN NEVADA AND

SOUTHEASTERN CALIFORNIA PROCESSED FRORECEIVED

U.S. GEOLOGICAL SURVEY 1-DEGREE DIGITAL APR 291996

ELEVATION MODEL DATA FILES

OSTI

U.S. GEOLOGICAL SURVEY

Open-File Report 95-287

Prepared in cooperation with the

NEVADA OPERATIONS OFFICE,

U.S. DEPARTMENT OF ENERGY under

Interagency Agreement DE-AI08-92NV10874

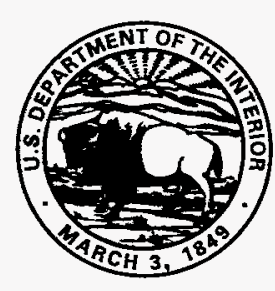




\title{
DIGITAL ELEVATION MODEL (DEM) FILE OF TOPOGRAPHIC ELEVATIONS FOR THE DEATH \\ VALLEY REGION OF SOUTHERN NEVADA AND SOUTHEASTERN CALIFORNIA PROCESSED FROM U.S. GEOLOGICAL SURVEY 1-DEGREE DIGITAL ELEVATION MODEL DATA FILES
}

\author{
by A. Keith Turner, Frank A. D'Agnese, and Claudia C. Faunt
}

\section{U.S. GEOLOGICAL SURVEY}

Open-File Report 95-287

\author{
DISCLAIMER
}

This report was prepared as an account of work sponsored by an agency of the United States Government. Neither the United States Government nor any agency thereof, nor any of their employees, makes any warranty, express or implied, or assumes any legal liability or responsibility for the accuracy, completeness, or usefulness of any information, apparatus, product, or process disclosed, or represents that its use would not infringe privately owned rights. Reference herein to any specific commercial product, process, or service by trade name, trademark, manufacturer, or otherwise does not necessarily constitute or imply its endorsement, recommendation, or favoring by the United States Government or any agency thereof. The views and opinions of authors expressed herein do not necessarily state or reflect those of the

Prepared in cooperation with the United States Government or any agency thereof.

NEVADA OPERATIONS OFFICE,

U.S. DEPARTMENT OF ENERGY under

Interagency Agreement DE-Al08-92NV10874

Denver, Colorado

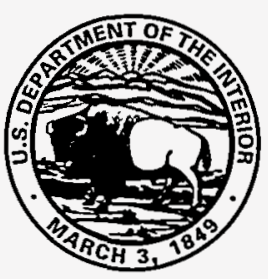




\section{CONTENTS}

Abstract
Introduction
Data source.....
Data processing procedures
Data limitations

\section{FIGURES}

1. Map showing area of study including location of Yucca Mountain, the Death Valley regional

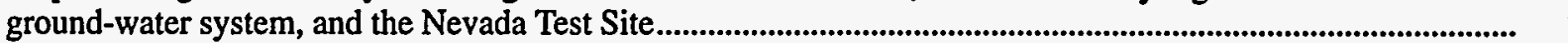

2. Diagram showing data structure for 3 -arc-second digital elevation models .............................................................. 3

3. Diagram showing standard USGS DEM 3-arc-second source files used and their corresponding map locations.

4. Shaded relief map compiled from processed DEM data with simulated illumination from an azimuth of $45^{\circ}$ and an altitude of $45^{\circ}$

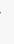




\title{
Digital Elevation Model (DEM) File of Topographic Elevations for the Death Valley Region of Southern Nevada and Southeastern California Processed from U.S. Geological Survey 1-Degree Digital Elevation Model Data Files
}

\author{
ByA. Keith Turner, Frank A. D'Agnese, and Claudia C. Faunt
}

\section{Abstract}

Elevation data have been compiled into a digital data base for an approximately 100,000 -square-kilometer area of the southern Great Basin, the Death Valley region of southern Nevada, and southeastern California, located between lat $35^{\circ} \mathrm{N}$., long $115^{\circ} \mathrm{W}$., and lat $38^{\circ} \mathrm{N}$., long $118^{\circ} \mathrm{W}$. The data were derived from U.S. Geological Survey 1-degree Digital Elevation Model data files distributed by the Earth Science Information Center. Because digital maps are often useful for applications other than that for which they were originally intended, and because the area covered by these files corresponds to a region under continuing investigation by several groups, these digital files are being released by the U.S. Geological Survey.

The elevation data obtained from the Earth Science Information Center were combined, resampled, and geographically transformed into the Universal Transverse Mercator coordinate system. The resulting grid is composed of 984 columns and 1,203 rows and corresponds to a square grid cell having a land-surface dimension of about 278.5 meters.

The data are provided in two file formats. One file contains 1,203 records and represents the basic gridded elevation data in a generic ASCII format. The elevations for each grid row are contained in a single record. The values within each row are stored in order from west to east. The records present the rows in sequence from south to north. The second file provides the same grid of elevations in ARC/INFO EXPORT format.

\section{INTRODUCTION}

Yucca Mountain, Nevada, is being studied by the U.S. Department of Energy as a potential site for construction of a repository for the permanent storage of high-level radioactive waste. As part of this project, the U.S. Geological Survey (USGS), in cooperation with the Department of Energy, has begun studies to describe the site and the regional geologic and hydrogeologic systems. This compilation of topographic elevation data is part of these studies.

This report provides a digital description of topographic elevations within a region that extends from lat $35^{\circ} \mathrm{N}$., long $115^{\circ} \mathrm{W}$. to lat $38^{\circ} \mathrm{N}$., long $118^{\circ} \mathrm{W}$. This region includes the Nevada Test Site, Yucca Mountain, and adjacent parts of southern Nevada and eastern California (fig. 1) and encompasses the Death Valley regional ground-water system (Bedinger and others, 1989). The topographic data were required by regional ground-water numerical modeling studies using Geographic Information System (GIS) methods. The digital files described in this report are available from the USGS, Denver, Internet repository via 'anonymous ftp' at ympbserv1.cr.usgs.gov.

\section{DATA SOURCE}

The Earth Science Information Center (ESIC) distributes several types of digital cartographic/geographic data files produced by the USGS as part of the National Mapping Program. One type of such files, termed a Digital Elevation Model (DEM), consists of a sampled array of elevations for a number of ground positions at regularly spaced intervals. ESIC currently supplies DEM data for selected quadrangles at four distinct scales or resolutions, namely: 7.5 -minute, 15-minute, 30-minute, and 1-degree. Some of these products are available only for specific geographic areas; for example, the 15- and 30-minute DEM prod- 
ucts are available only for Alaska. All these DEM products have almost identical digital file structures that are described in detail, along with other supporting documentation concerning data sources, data accuracies, and similar information, in a Data Users Guide (U.S. Geological Survey, 1990).

The Death Valley region DEM described in this document was developed from 1-degree DEM data files distributed by ESIC. These 1-degree DEM products have the following characteristics:

- The product consists of a regular array of elevations referenced horizontally on the geographic (latitude/longitude) coordinate system of the World Geodetic System 1972 Datum (WGS 72) or the World Geodetic System of 1984 (WGS 84).

- The unit of coverage is a 1-by 1-degree block. Elevation data on the integer degree lines on all four sides correspond to the same points on the surrounding eight blocks.

- Individual files are identified by the name of the corresponding 1:250,000-scale 1- by 2-degree topographic map sheet, followed by the designation "east" or "west" to reference the appropriate 1- by 1-degree block.
- Elevations are provided in meters relative to the National Geodetic Vertical Datum of 1929 (NGVD 29) in the continental United States.

- The data are ordered from south to north in profiles that are ordered from west to east (fig. 2).

- Spacing of the elevations along each profile is 3-arc-seconds of latitude. The first and last data points are at the integer degrees of latitude. A profile will, therefore, contain 1,201 elevations.

- Within the continental United States, the spacing between profiles is 3-arc-seconds of longitude. The first and last profiles are at the integer degrees of longitude, and there are 1,201 profiles per 1-degree block.

The 3- by 3-degree Death Valley region (fig. 1) required nine 1-by 1-degree DEM data files defined in table 1 and figure 3 . Each 1 - by 1-degree block is defined by an array of 1,201 by 1,201 elevation values, resulting in a total of $1,442,401$ elevation values. These data files are in ASCII-format and, therefore, each file requires greater than 8-Mbytes of data storage. The total area of the Death Valley region at the same resolution would require an array of 3,601 by 3,601 elevation values and more than 72-Mbytes of data storage. Such a large volume of data is unwieldy

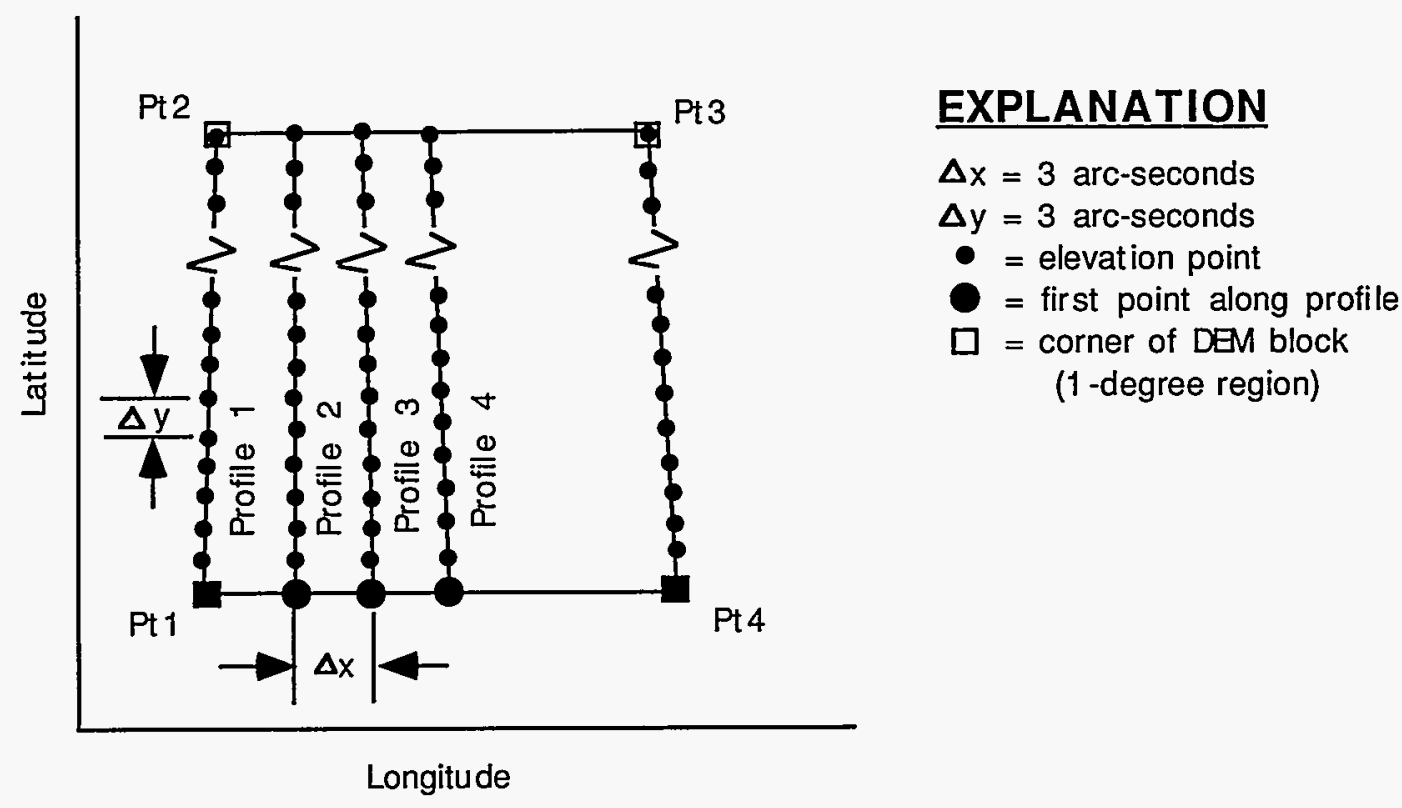

Figure 2. Data structure for 3-arc-second digital elevation models. 
by the project. Accordingly, the existing 1-degree DEM data were resampled and processed by the methods described in the following sections to produce a smaller and more suitable DEM data file.

These thinned elevation data arrays retain a definition of topographic conditions within the entire study area that may prove useful to other mapping applications at scales of $1: 500,000$ or smaller. The thinning of the data results in a loss of definition of smaller topographic features. A common problem encountered in many of the USGS 1-degree DEM data sets is a "striping" effect caused by minor elevation oscillations between adjacent rows in the elevation matrix. Such oscillations become evident when topographic slope and aspect conditions are computed from the elevation values and displayed as shaded relief maps. The resampling and thinning appears to have reduced the effects of any such small-amplitude elevation variations between adjacent grid rows. Thus, shaded relief maps (such as fig. 4) developed from this processed elevation data provide a good representation of the region. However, the wider spacing of the elevation grid results in the computation of more generalized slope and aspect values that do not necessarily reflect small-scale landforms or precisely correspond to local slope and aspect conditions.

\section{DATA PROCESSING PROCEDURES}

The nine 1- by 1-degree DEM data files defined in table 1 and figure 3 were obtained as standard ninetrack magnetic tape products from ESIC. These files were initially converted to a single large-grid file using two products from Intergraph Corporation's Modular GIS Environment (MGE) family of software products. MGE Digital Terrain Model Translators (MGE_DT) is a software product developed by Intergraph Corporation for the translation of DEM files produced by both the USGS and the Defense Mapping Agency (DMA) into file formats that can be used by other Intergraph MGE products (Intergraph, 1992a). The MGE Grid Analyst (MGGA) product allows for the further manipulation of grid files (Intergraph, 1992b).

The MGE_DT product was used to load and merge the nine 1-by 1-degree DEM files into an Intergraph MGE project data base. This data base recognized that these data contained elevations in meters, with the grid spacings in the $\mathrm{x}$ - and $\mathrm{y}$-directions specified as 3 seconds of arc in latitude and longitude. The correct geographic extents for these data were also defined in this data base (lat $35^{\circ} \mathrm{N}$., long $115^{\circ} \mathrm{W}$. to lat $38^{\circ} \mathrm{N}$., long $118^{\circ} \mathrm{W}$.). The resulting merged file contained 3,601 columns and 3,601 rows of elevation values, required an extremely large amount of disk storage space, and required a long time to display the data, even on a relatively fast graphics work station.

Consequently, for reasons of practicality and economy, the merged grid was thinned in both the $\mathrm{x}$ - and $\mathrm{y}$-directions by retaining only every third column and every third row elevation value. This was accomplished by using the "Thin Grid" command within the Intergraph MGGA product. The new values were defined by selecting every third column and row elevation value without interpolation of surrounding data values. The resulting thinned grid file contained 1,201 columns and 1,201 rows of elevation values, and thus, was comparable in size and speed of display to a single 1- by 1-degree DEM file.

The thinned grid file was still in a proprietary Intergraph MGE grid file format. It continued to represent elevations in meters, with a grid spacing of 9 arc-seconds of latitude and longitude. It did not represent the data in any map projection, and the MGGA software treated the grids as perfect squares when, in fact, they were not. Conversion of this grid to reflect map projection standards and true ground dimensions in meters was done with the ARC/INFO Grid product (Environmental Systems Research Institute, 1991; 1992).

The reduced grid was exported from the Intergraph MGGA product using the "GridtoAscii" command. This produced a generic ASCII file containing an array of elevation values with 1,201 columns and 1,201 rows. The data array was produced in columnmajor order, reading from south to north on each column, and with columns scanned in sequence from west to east. Accordingly, the first elevation value was for the southwest corner, and the last elevation value was for the northeast corner.

This ASCII file was read directly into the ARC/INFO Grid product using the ARC "asciigrid" command. The grid was defined as having a "Geographic Projection." In the ARC/INFO software, this term represents data that have $x$ - and $y$-positions defined solely in terms of degrees of latitude and longitude. Using the ARC "project" command, the initial grid was transformed into the Universal Transverse Mercator (UTM) coordinate system by using a bi-linear interpolation method.

The "project" command produces truly square (equidimensional) grid cells and also requires some angular rotations to satisfy the map projection parameters. Since the ground dimensions of the 9 arc-second latitude-longitude grid cells were approximately 210 meters in the east-west direction by 270 meters in the north-south direction, resampling was necessary to produce equidimensional grid cells. The ARC "project" command produced a square grid-cell 
dimension of about 278.5 meters and resulted in a UTM-registered grid composed of 984 columns and 1,203 rows. Table 2, produced by the ARC "describe" command, defines the parameters for this UTM grid.

\section{DATA LIMITATIONS}

This elevation data set was derived from USGS 3-arc-second 1-by 1-degree DEM files. The accuracy of these data and their fitness for particular applications are restricted by the basic accuracy of the source data and by the thinning and resampling actions taken in creating this data set.

\section{Location Accuracy}

The USGS classifies all DEM products into three levels, ranging from Level 1 (reserved for interim 7.5-minute quadrangle DEM data) to Level 3 (the most accurate at a given scale). All 1- by 1-degree DEM's are classified as Level 3 because the hypsometric information, when plotted as contour lines at 1:250,000 scale, is consistent with the planimetric features normally found on 1:250,000-scale topographic maps. The production criteria were to provide an absolute horizontal accuracy of $\mathbf{1 3 0}$ meters circular error at 90-percent probability. Inconsistencies may exist, but they are isolated cases that are reflected by the 90-percent confidence level for the overall product (U.S. Geological Survey, 1990).

\section{Elevation Accuracy}

The published topographic maps at 1:250,000 scale show topographic elevations in feet; however, the standard DEM files define these elevations in meters. The original production objective for the 3-arc-second DEM's was to provide an absolute vertical accuracy related to mean sea level of \pm 30 meters with a 90-percent probability. This absolute accuracy may be too strict as a measure of vertical accuracy, however, Level 3 DEM's also are defined as having a RootMean-Square-Error (RMSE) of elevation values equal to one-third the contour interval and no errors greater than two-thirds the contour interval. Because the source maps in this region have contour intervals of about 30 or 60 meters (100 or 200 feet), corresponding RMSE values no greater than 10 or 20 meters may be expected. Furthermore, USGS documentation reports concerning DEM data files state: "The relative horizontal and vertical accuracy (feature-to-feature on the surface of the elevation model), although not specified, will in many cases conform to the actual hypsographic features with higher integrity than indicated by the absolute accuracy." (U.S. Geological Survey, 1990, pp. 13-14). In other words, errors in the relative elevation of nearby features may be considerably less

Table 2. Specifications of the UTM-registered DEM

\begin{tabular}{|c|c|c|c|}
\hline \multicolumn{4}{|c|}{ Description of Grid/HOMEBASE/FDAGNESE/DEMDATA/NEWGRDUTM } \\
\hline Cell size $=$ & 278.494 & \multicolumn{2}{|c|}{ GRID SIZE } \\
\hline Data type: & $\begin{array}{l}\text { Floating point } \\
\text { IDARY }\end{array}$ & $\begin{array}{l}\text { Number of rows }= \\
\text { Number of columns }= \\
\text { STATIS }\end{array}$ & $\begin{array}{r}1,203 \\
984 \\
\end{array}$ \\
\hline $\mathrm{Xmin}=$ & 408629.174 & Minimum value $=$ & -77.278 \\
\hline$X \max =$ & 682667.485 & Maximum value $=$ & 3500.010 \\
\hline$Y \min =$ & 3872707.059 & Mean $=$ & 1233.970 \\
\hline$Y \max =$ & $\begin{array}{r}4207735.604 \\
\text { COORDINA }\end{array}$ & $\begin{array}{l}\text { Standard deviation = } \\
\text { YSTEM DESCRIPTION }\end{array}$ & 515.087 \\
\hline Projection & UTM & & \\
\hline Zone & 11 & & \\
\hline $\begin{array}{l}\text { Units } \\
\text { Parameters: }\end{array}$ & METERS & Spheroid & CLARKE1866 \\
\hline
\end{tabular}


Environmental Systems Research Institute, 1991, Cell based modeling with GRID: Redlands, Calif., Environmental Systems Research Institute, $333 \mathrm{p}$.

1992, GRID command references-Operators, statements, and commands (revised ed.): Redlands, Calif., Environmental Systems Research Institute, 2 vols., [variously paged].

Intergraph, 1992a, MGE digital terrain model translators (MGE_DT) user's guide: Huntsville, Ala., Intergraph Corporation, Document DJA054630, 88 p.

1992b, MGE grid analyst (MGGA) reference manual: Huntsville, Ala., Intergraph Corporation, Document DJA052960, 426 p.
U.S. Geological Survey, 1990, Digital elevation models (revised ed.): Reston, Va., National Mapping Program, Technical Instructions, Data Users Guide 5, 51 p.

\section{CITATION:}

Turner, A. Keith, Frank A. D'Agnese, and Claudia C. Faunt, 1996. Digital Elevation Model (DEM) file of topographic elevations for the Death Valley Region of southern Nevada and southeastern California processed from U.S. Geological Survey 1-Degree (3-arc-second) Digital Elevation Model (DEM) data files. U.S. Geological Survey Open-File Report 95-287. ARC/INFO Export format. 